\title{
Dental caries in mother-child pairs from Xingu
}

\author{
Lucila Brandão Hirooka' ${ }^{1}$, Wilson Mestriner-Junior' ${ }^{2}$, Soraya Fernandes Mestriner ${ }^{2}$, \\ Selma Aparecida Chaves Nunes ${ }^{2}$, Pablo Natanael Lemos ${ }^{3}$, Laércio Joel Franco ${ }^{1}$
}

\author{
${ }^{1}$ Universidade de São Paulo - USP, Medical School of Ribeirão Preto, Department of Community Medicine, Ribeirão Preto, SP, Brasil \\ ${ }^{2}$ Universidade de São Paulo - USP, School of Dentistry of Ribeirão Preto, Department of Pediatric Dentistry, Ribeirão Preto, SP, Brasil \\ ${ }^{3}$ Universidade de São Paulo - USP, Project Xingu, São Paulo, SP, Brasil
}

Received for publication: December 05, 2013 Accepted: March 17, 2014

Correspondence to: Laércio Joel Franco

Departamento de Medicina Social, Faculdade de Medicina de Ribeirão Preto Universidade de São Paulo, Avenida Bandeirantes, 3900

CEP: 14049-900 - Ribeirão Preto, SP, Brasil

Phone: +55 166022536

Fax: +55 166331386

E-mail: Ifranco@fmrp.usp.br

\begin{abstract}
Aim: To describe cases of dental caries in Indian mother-child pairs of the middle and lower Xingu River - Xingu Indigenous Park. Methods: A total of 246 children aged 3-5 years old and their respective mothers took part in this study. Caries indexes dmft and DMFT were analyzed for deciduous and permanent dentitions, respectively, according to criteria proposed by the World Health Organization. Results: Analysis of the DMFT index showed a mean value of 14.3 for mothers. In mothers aged between 35 and 44 years, tooth loss accounted for more than $80 \%$ of the total index score. With regard to the children, dmft index was 4.7 , on average, and only $13.4 \%$ were caries-free. No significant correlation was found between mother and child caries experience $(p=0.16)$. Conclusions: These results suggest that it is important to consider the community as a whole, and not only the mother, regarding the oral health of indigenous children. Community should be involved in the planning of strategies for caries prevention and health promotion, taking into account the socio-cultural complexity and specificities of indigenous population and adapt them to the local reality for these strategies to become actually effective.
\end{abstract}

Keywords: oral health; dental caries; mother-child relations; Indians; South American.

\section{Introduction}

Oral health is a determining factor for quality of life and personal development, and according to the World Health Organization (WHO), political, social, economic, cultural, environmental, behavioral and biological factors may improve or impair oral health ${ }^{1}$.

With regard to mother-child relationships, microbiological studies have associated the mother's salivary levels of $S$. mutans to the degree of colonization and/or caries experience in her children ${ }^{2}$. Other studies show a positive relationship between mother and child caries experience, suggesting that this is a good predictor of caries risk in children ${ }^{3}$.

In the etiological context of caries disease, bacterial infection is necessary but it is not the sole factor contributing to its development, since occurrence and severity of caries in a population result from an interaction with the causing elements ${ }^{4}$. Dental caries in childhood is strongly related to the mother, who not only is a transmitter of bacteria but also the model of habits, values and attitudes for her child 5 .

According to $\operatorname{Arantes}^{6}$ (2010), it is possible to notice a common course of the oral health in indigenous people when they have permanent contact with settler societies. Socioeconomic, cultural and political changes resulting from such a process interfere with the subsistence food supply and introduce new 
types of foods, thus altering oral health patterns. However, socioeconomic, environmental and cultural determinants, which are highly complex and diversified, assume a particular role in relation to indigenous ethnic groups.

The Xingu Indigenous Park (XIP) was established in 1961, according to the Act 51.084 signed by the then President of Brazil on 31 July, 1961, mainly aiming to ensure medical, social and educational support for indigenous people so that they could survive physically and have their culture preserved $^{7}$. Partnerships with National Health Foundation (FUNASA), Federal University of São Paulo (UNIFESP) and the School of Dentistry of Ribeirão Preto (FORP-USP) have been established in order to promote an improvement in the oral health conditions of the middle and lower Xingu River population.

This work is intended to describe dental caries experience in mother-child pairs living in the XIP (middle and lower Xingu region) in 2007.

\section{Material and methods}

A descriptive study was performed from data collected by the Epidemiological Survey on Oral Health in Middle and Lower Xingu conducted in 2007. The entire XIP's indigenous population - covering the area of the middle and lower Xingu - were invited to participate in the study, provided that they were present at the moment of examination. A total of 1,911 individuals were examined, $83.12 \%$ of the population. The clinical examinations were performed by 5 calibrated examiners (kappa $=0.91$ ) assisted by Oral Health Indigenous Agents (AISB), with natural light, using a dental mirror and WHO probe (Hu-Friedy, Chicago, IL, USA), using the methodology recommended by the $\mathrm{WHO}^{8}$. Data were processed using the Brazilian Ministry of Health's SB Data software?.

\section{Local of Research}

The XIP covers an area of 2.8 million ha in the northern region of Mato Grosso State, Brazil. In the middle and lower
Xingu region, there are approximately 2,299 indigenous individuals from several ethnical groups, including Kisêdje, Tapayuna, Kaiabi, Ikpeng, Yudjá, Mehinaku, Waurá, Panará, Kamaiurá and Trumai.

\section{Study Population}

Children aged between 3 and 5 years who participated in the epidemiological survey with their respective mothers were selected for study. Six mother-child pairs were excluded because their mothers were older than 45 years. Therefore, 246 mothers and 246 children were examined.

Mother and child experience of dental caries was analyzed using DMFT and dmft indexes, respectively.

The research project was approved by the Research Ethics Committee of the School of Dentistry of Ribeirão Preto, University of São Paulo (Process 2010.1.33.58.0).

For data analysis, tables and graphs were used as well as distribution of absolute and relative frequencies, in addition to mean values and standard deviations at significance level of 5\%. Spearman's correlation coefficient was employed to verify the correlation between DMFT and dmft indexes.

\section{Results}

The mean age of the mothers was 27.7 years old, with minimum of 15 and maximum of 44 years. Analysis of the DMFT index showed a mean value of 14.3 for mothers. In the age group of 35-44 years, tooth loss was the component responsible for more than $80 \%$ of the total index scores (Table 1).

Analysis of the dmft index showed a mean value of 4.7 for children, reaching maximum value (6.4) in the age group of 60-71 months old. Caries was the component most contributing to $\mathrm{dmft}$ index in all age groups. The prevalence of dental caries in indigenous children was $86.6 \%$. In the age group of 48-59 months, it was observed that $95.2 \%$ of the children had already experienced dental caries in their deciduous dentition (Table 2).

No significant correlation was found between mother and child dental caries experience $(p=0.16)$.

Table 1. Mean (standard deviation) and percentage of DMFT index components according to mother age groups.

\begin{tabular}{|c|c|c|c|c|c|c|c|c|c|}
\hline \multirow{2}{*}{$\begin{array}{l}\text { Age group } \\
\text { Mother (years) }\end{array}$} & \multirow{2}{*}{$\mathbf{n}$} & \multicolumn{2}{|c|}{ Decayed } & \multicolumn{2}{|l|}{ Lost } & \multicolumn{2}{|l|}{ Filled } & \multicolumn{2}{|c|}{ DMFT } \\
\hline & & Mean (SD) & $\%$ & Mean (SD) & $\%$ & Mean (SD) & $\%$ & Mean (SD) & $\%$ \\
\hline $15-24$ & 81 & $0.8(1.2)$ & 8.7 & $2.7(2.9)$ & 27.2 & $6.4(2.9)$ & 64.1 & $10.0(4.5)$ & 100.0 \\
\hline $25-34$ & 82 & $1.5(2.2)$ & 9.8 & $7.6(6.1)$ & 49.0 & $6.4(3.3)$ & 41.2 & $15.5(5.9)$ & 100.0 \\
\hline $35-44$ & 43 & $0.5(1.3)$ & 2.6 & $16.2(6.4)$ & 80.6 & $3.3(3.3)$ & 16.8 & $20.2(4.5)$ & 100.0 \\
\hline Total & 206 & $1.0(1.7)$ & 7.4 & $7.5(7.2)$ & 52.3 & $5.7(3.4)$ & 40.3 & $14.3(6.4)$ & 100.0 \\
\hline
\end{tabular}

Table 2. Mean (standard deviation) and percentage of dmft index components according to child age groups.

\begin{tabular}{|c|c|c|c|c|c|c|c|c|c|c|}
\hline \multirow{2}{*}{$\begin{array}{l}\text { Age group } \\
\text { Child (months) }\end{array}$} & \multirow{2}{*}{$\mathbf{n}$} & \multicolumn{2}{|c|}{ Delayed } & \multicolumn{2}{|l|}{ Lost } & \multicolumn{2}{|l|}{ Filled } & \multicolumn{2}{|c|}{$\mathrm{dmft}$} & \multirow{2}{*}{$\begin{array}{c}\text { Caries } \\
\%\end{array}$} \\
\hline & & Mean (SD) & $\%$ & Mean (SD) & $\%$ & Mean (SD) & $\%$ & Mean (SD) & $\%$ & \\
\hline $36-47$ & 92 & $2.4(2.7)$ & 82.9 & $0.1(0.6)$ & 4.2 & $0.4(0.8)$ & 12.9 & $2.9(2.9)$ & 100.0 & 72.8 \\
\hline $48-59$ & 63 & $4.0(3.4)$ & 80.5 & $0.3(0.7)$ & 6.1 & $0.7(1.3)$ & 13.4 & $4.9(3.6)$ & 100.0 & 95.2 \\
\hline $60-71$ & 91 & $4.6(3.3)$ & 71.1 & $0.5(1.0)$ & 7.5 & $1.4(1.6)$ & 21.4 & $6.4(3.7)$ & 100.0 & 94.5 \\
\hline Total & 246 & $3.6(3.3)$ & 76.3 & $0.3(0.8)$ & 6.4 & $0.8(1.4)$ & 17.3 & $4.7(3.7)$ & 100.0 & 86.6 \\
\hline
\end{tabular}




\section{Discussion}

The oral health of mother-child pairs was characterized by high prevalence of dental caries in children and significant tooth loss in mothers. Also, the mother and child experience of dental caries tended to increase with age, a common phenomenon if one considers the cumulative character of DMTF and dmft indexes ${ }^{10}$.

Comparing the data on the children's caries experience to those obtained from the Brazilian Ministry of Health national epidemiological survey on oral health conditions ${ }^{9}$, it may be observed that, at 5 years of age, the mean $\mathrm{dmft}$ values were greater than those reported in this study (6.4 vs. 2.8 , respectively). With regard to the prevalence of dental caries, the national rate is almost $60 \%$, whereas the great majority of the indigenous children experienced caries in at least one deciduous tooth $(94.5 \%)$, which is far from the WHO proposed goal for the year 2000 (50\% of caries-free children).

The severity of children's dental caries, expressed by $\mathrm{dmft}$ index values found in the present study, is close to the one reported by Carneiro et al. ${ }^{11}$ (2008) for Baniwa 5-yearold children ( 6.4 vs 6.3 , respectively). For the author, besides the factors related to high levels of caries observed in that community, it should be pointed out that the distribution of oral hygiene materials by the Alto Rio Negro Indian Special Sanitary District to a high-risk population was interrupted. In the XIP, the problem regarding distribution of oral hygiene material is alleviated by donations from dental manufacturers. However, not only distribution is currently unavailable, but also there is neither enough material nor logistics for the delivery to the villages.

An increase in the proportion of tooth loss with age was observed in indigenous mothers. Detogni ${ }^{12}$ (1994) states that Xingu native population accept "naturally" the dental loss as if the absence of a substantial number of teeth was something to be expected in life, a fact possibly associated to the aggravating process of oral health conditions.

The high contribution of tooth loss among mothers may reflect a greater access to dental services, but it may also mean difficult access to secondary healthcare services. In the XIP, high demand, difficult transportation from village to town, and low supply of secondary services in the neighboring towns, among other factors, compromise the establishment of reference and counter-reference networks. Despite the importance of these networks, we agree with Palmier et al. ${ }^{13}$ (2012), who state that socio-economic changes play a more prominent role in the reduction of dental caries indexes among children than the contribution of healthcare services.

Several authors have studied the association between oral health conditions of mothers and children. Noce et al. ${ }^{14}$ (2008) reported that the presence or absence of caries in children was not associated with the level of dental caries in their parents. In their study, no correlation between mother and child experiences of dental caries was observed.

According to Laitala et al. ${ }^{3}$ (2012), S. mutans colonization avoided at early ages may lead to favorable long-term effects on caries experience in children. However, caries is a multifactorial disease and no isolated variable, biological, social, economic or cultural, seems to be able to predict its development ${ }^{5}$.

Indigenous children are nurtured in an environment of great freedom, and the elderly pass their knowledge on through oral tradition to the young people. Although the parents are the main caregivers, the wider socialization process of indigenous children is also conducted by close relatives as well as by the community as a whole ${ }^{15}$.

According to Mattila et al. ${ }^{16}$ (2000), attention to the children's oral health alone is not enough. It is necessary to address the factors related to the family and community habits and lifestyle in order to promote health maintenance rather than treatment and control of the disease. Therefore, it is important to consider the entire community and not only the mothers in the oral health of indigenous children.

Pacagnella $^{17}$ (2007) observed an improvement in the caries levels during the 2001-2006 period in the XIP for most of the age groups. Such a decline may be related to various factors. The establishment of Indigenous Special Sanitary Districts in 1999 allowed political stability and increased the federal investment in the healthcare of indigenous people. As a result of the partnerships with FORPUSP and dental manufacturers, indigenous people started having wider access not only to dental services, but also to educative and preventive programs ${ }^{18}$. The partnerships also allowed the conduction of the "Epidemiological Survey of Oral Health Conditions of Middle and Lower Xingu" in 2007 to collect data on the oral health conditions and support the planning/evaluation of actions at different management levels in this area. This survey enabled the studies that clarify oral health conditions of the middle and lower Xingu as well as mother-child pairs in this region.

Nevertheless, the high caries indexes found may be related to an increase in the contact between Xingu people and settler's society. The Xingu Indigenous Park has a geographically limited area, which is subject to the impact of the advance of the agricultural activity of logging and mining fields. The emergence of new cities and highways in the neighborhood intensify the contact relationships, resulting in changes that made the people of the Xingu Indigenous Park more vulnerable to certain diseases. A more sedentary lifestyle has been observed, a result of changes in the way of life due to the introduction of technologies and wages of Indians who participate in various activities organized by institutions working in the $\mathrm{Xingu}^{6}$. The increased mobility of the Indigenous population and the visits to nearby cities have also contributed to the change in eating habits ${ }^{19}$. Industrialized food has been increasingly introduced and replacing the traditional foods, which impairs child nutrition and raises the levels of dental caries ${ }^{6,19}$.

The model of health care that has was been consolidated seeks to provide answers to key problems arising from social and historical process of contact between Indians and settlers, prioritizing intersectoral actions and the growing involvement of Xingu population ${ }^{20}$. Furthermore, the importance of promotion and prevention of both the collective 
and individual, decentralized and multiplicative, with the purpose of promoting the interaction of oral health teams, indigenous individuals and indigenous health agents, who are the pillars of the education process continued in communities. The current epidemiological scenario of the oral health of Xingu indigenous mothers and children unravels the importance of evaluating periodically the oral healthcare services and re-structuring the already developed work by identifying new needs.

The findings of this study show that the whole community, and not only the mothers, should be considered in the oral health of the indigenous children. The community should be involved in the planning of strategies for caries prevention and health promotion, adapted to local reality, so that they can be really effective.

\section{References}

1. World Health Organization. The World Oral Health Report, 2003. Continuous improvement of oral health in the 21 st century - the approach of the WHO Global Oral Health Programe. Geneve: World Health Organization; 2003.

2. Zhan L, Tan S, Den Besten P, Featherstone JD, Hoover Cl. Factors related to maternal transmission of mutans streptococci in high-risk childrenpilot study. Pediatr Dent. 2012; 34: 86-91.

3. Laitala M, Alanen P, Isokangas P, Söderling E, Pienihäkkinen K. A cohort study on the association of early mutans streptococci colonisation and dental decay. Caries Res. 2012; 46: 228-33.

4. Gomes D, Daros MA. The etiology of caries: the construction of a thoughtstyle. Ciênc. Saúde Coletiva 2008; 13: 1081-090.

5. Reisine S, Tellez M, Willem J, Sohn W, Ismail A. Relationship between caregiver's and child's caries prevalence among disadvantaged African Americans. Community Dent Oral Epidemiol. 2008; 36: 191-200.

6. Arantes R, Santos RV, Frazão P. Oral health in transition: the case of Indigenous peoples from Brazil. Int Dent J. 2010; 60: 235-40.

7. Brazil. Decree-Law n. ${ }^{\circ}$ 51.084. 1961 July 31.

8. World Health Organization. Oral health surveys: basic methods. 4.ed. Geneva: ORH/EPID; 1997.

9. Brazil. Health Ministry of Brazil. SB Brazil 2003 Project - Oral health conditions of the Brazilian population 2002-2003. Brasília, DF; 2004. 68p.

10. Cogulu D, Ersin NK, Uzela A, Eronat N, Aksit S. A long-term effect of caries-related factors in initially caries-free children. Int J Paed Dent. 2008; 18: 361-7.

11. Carneiro MCG, Santos RV, Garnelo L, Rebelo MAB, Coimbra Jr CEA. Dental caries and need for dental care among the Baniwa Indians, Rio Negro, Amazonas. Ciec Saude Colet. 2008; 13: 1985-92.

12. Detogni AM. Back to basics. Rev ABO Nac. 1994; 2: 138-48.

13. Palmier AC, Andrade DA, Campos ACV, Abreu MHNG, Ferreira EF. Socioeconomic indicators and oral health services in an underprivileged area of Brazil. Rev Panam Salud Publica. 2012; 32: 22-9.

14. Noce E, Rubira CMF, Rosa OPS, Silva SMB, Bretz WA. Streptococcus mutans Acquisition and Dental Caries Development in First-Born Children. Pesq Bras Odontoped Clin Integr. 2008; 8: 239-44.

15. Silva AL, Macedo AVLS, Nunes A. Indigenous Children - Anthropological Essays. São Paulo: Global Editora; 2002.

16. Mattila ML, Rautava P, Sillanpaa M, Paunio P. Caries in five year-old children and associations with family-related factors. J Dent Res. 2000; 79: 875-81.

17. Pacagnella RC. Epidemiological Profile of Oral Health of the Population of the Xingu Indigenous Park, between the years 2001 and 2006 [doctoral thesis]. Ribeirão Preto: Faculty of Medicine of Ribeirão Preto, São Paulo University; 2007. 101p.
18. Mestriner S F, Lemos PN, Hirooka LB, Nunes SAC, Arantes R, Mestriner $\mathrm{Jr}$ W. The oral health care model in Middle and Low Xingu: partnerships, processes, and perspectives. Cienc Saude Colet. 2010; 15: 1449-56.

19. Rodrigues D. The Federal University of São Paulo, the Xingu Project and Policy Attention to Health of Indigenous Peoples. In: Baruzzi R, Junqueira C, editors. Xingu Indigenous Park: health, culture and history. São Paulo: Federal University of São Paulo /Terra Virgem; 2005. p. 259-73.

20. Mesquita LP, Lemos PN, Hirooka LB, Nunes SAC, Mestriner SF, Taba $\mathrm{Jr} \mathrm{M}$, et al. Periodontal status of an indigenous population at the Xingu Reserve. Braz J Oral Sci. 2010; 9: 43-7. 